

\title{
4
}

\section{Water, Dams and Infection: Asian Challenges}

\author{
Adrian C Sleigh
}

\section{Introduction}

Throughout Asia, the growing needs and aspirations of the huge population now engaged in very rapid economic development are placing great strains on the ecosystem. Hydrological resources are under particular stress (Pearce, 1992; World Commission on Dams, 2000). For example, the Yangtze and Ganges river valleys, with 224 and 375 persons per square $\mathrm{km}$, respectively, support many more people than comparable river valleys in the Americas. Throughout most of Asia, the surface and underground water is increasingly polluted by animal and human excreta, poisoned by factory and agricultural effluents, withdrawn for agriculture, industry and households, and manipulated for navigation, flood control and power generation. National goals for economic development, safe water supplies, food security and good health are competing, even colliding. Central to meeting many of the above demands, especially those relating to food, water and economic development, are large dams and irrigation systems. Thousands have already been built in Asia. Indeed, China and India together now have over half the global total of large dams. It seems certain that thousands more large dams will be commissioned over the next two to three decades. Once 
again, China and India will account for most of them. The dams themselves will pose additional risks to already stressed ecosystems, but the water and the energy that they provide will also enhance many lives. Unfortunately, millions will be adversely affected and dam-associated infectious diseases will play a significant role in generating such negative effects. Given the large proportion of the dams that will be located in Asia, this topic is of special importance in that region.

Dams and their reservoirs transform the environment. A set of riverrelated resources such as water, fauna, flora and landscape are converted into another set of natural resources. The fauna and flora are changed, often completely, and even the climate can alter with rising humidity and temperature. The water table rises, fish no longer migrate, people and animals cannot traverse the landscape, farmland is submerged, people are displaced and livelihoods are destroyed. A large lake appears, but its level fluctuates in unnatural ways and it often becomes polluted. Downstream flows are altered as well, with great changes forced upon the agricultural system, alteration of fisheries and estuaries, erosion of flood dykes due to lack of silt below the dam, and decreased river flow due to upstream extraction for irrigation. Ancestral graves and archaeological sites are flooded. Another group of people and animals, often remote from the dam site, benefits from these changes, with generation of power and water supplies for domestic and industrial use. There are always winners and losers. When the losers are indigenous people, with traditional lives and lands lost, they cannot recover as their culture is place-based and unique. With increasing construction of very large dams (more than 150 metres in height) Asian river valleys are being affected at an alarming rate, with dense population areas now considered for dam developments. This means that displaced populations are also increasing, with the Three Gorges Dam in China as a good example with nearly two million people displaced from the reservoir area, and hundreds of millions affected downstream.

In this chapter, I review the general attributes of large dams, consider their documented impacts on infections, and suggest ways that the development community can integrate resources to mitigate these unwanted health effects. My interest in this topic first arose when I studied water-related diseases in Brazil many years ago. This made me consider the link between agriculture, water and infection. I worked in some areas that were irrigated, visited 
several large dams and encountered many people displaced and marginalised by one large dam. Later, I had the opportunity to join the impact mitigation teams working on large dams in China, including the two biggest, Three Gorges Dam on the Yangtze river and the World Bank-financed Ertan Dam on the Yalong river, $1,000 \mathrm{~km}$ further upstream (Sleigh and Jackson, 1998, 2001; Jackson and Sleigh, 2000, 2001). I worked with experienced Chinese and international colleagues and learned much from them about big dams, their ecological and social impacts, and the furious debate then (and now) raging about the role of dams in development (Alvares and Billorey, 1988; Morse and Berger, 1992; Fearnside, 1994; Dorcey et al., 1997; Cernea, 1988, 1999; McCully, 2001). However, I was usually the

sole health person on the team, so under-resourcing health assessments and constraining mitigation of health impacts even when the social and ecological impacts were being seriously considered by the dam builders. But this was better than previous practice, as most earlier dams were built without giving the health sector any voice at all (Hunter et al., 1993; World Health Organization, 1999).

\section{Dams, Population and Development}

Human societies have constructed dams for most of recorded history. As far as we know, hydraulic works began with civilisation itself. We know that Mesopotamians built dams and irrigation canals 8,000 years ago and town water supply systems have been used in the Middle East since 3,000 BC. Ancient water systems and dams were also built in Asia and South America and the capture of energy from flowing water was practised in ancient Egypt and Sumeria, using wheels and buckets.

Taking a long view of history, one could argue that the most successful agricultural development arose in China. Dams and water played a major role, but the environmental toll has been great and the next 100 years will be the most challenging that China has ever faced. A huge population, associated pollution, progressive northern desertification, sinking aquifers and rivers that no longer reach the sea are the legacy of this past success. The economic historian David Landes attributes China's precocious and (until now) long-lasting agricultural success to its early focus on hydraulic works 
and irrigation (Landes, 1998). In this much praised book, he examines and attempts to explain the wealth and poverty of nations. Landes notes that the 2,500 year-old Chinese strategy of ensuring political survival and economic development of the Han by stimulating and enabling their rapid demographic growth. The population growth required a commensurate increase in the food supply, achieved by adopting labour-intensive agriculture. Intensive agriculture was in turn enabled by the demographic growth, requiring more agricultural production and creating a treadmill effect and more population growth. Underpinning this development strategy in China was the invention, construction and the firm central control of dams and irrigation at that time. The process began in the rich loess soils of the Upper Yellow river, a veritable school for water control, irrigation technology and adaptation of water buffalo as draft animals. The population then expanded further down that same river basin where floods and droughts were later to affect large settled populations, becoming China's "Sorrow". Eventually, after 2,500 years of human manipulation of the river water for storage, irrigation, flood control and finally power generation, the Yellow river began to run dry before reaching the sea. Currently, the lower reaches of the river are dry on most days of the year and the surrounding region, including Beijing, has a severe water shortage.

Eventually, beginning about 1,300 years ago, the Han expanded south into the warmer and wetter Yangtze and Pearl river basins, embracing irrigated rice and double or triple annual cropping, substantially boosting caloric yields and population growth. This water-based development of labourintensive agriculture led to Wittfogel's political theory that the required 'hydraulic centralism' inevitably produced an autocratic form of government, which he injudiciously named Oriental Despotism (Wittfogel, 1957). Landes concurs that the intensive Chinese system of irrigated agriculture led to the need for absolute central power over a critical and ever-growing system of big dikes, dams, canals, flood control, repair and relief. It is not hard to link such historical descriptions to the situation prevailing in China today, with the obvious preoccupation with maintaining the water-based food supply for its now huge population. This is a direct result of 2,500 years of hitherto successful and always inventive hydraulic manipulation of the national ecosystem, and its central engineer-focused decision making for matters dealing with large dams, flood control, irrigation and water supply. 
It remains to be seen whether such central control can now rescue China from its looming environmental fate, with widespread soil erosion, severe water pollution, and a population that is almost too large for the available water supplies.

While China developed technologically, Europe did not do so well in the field of dam development, at least for the first 2,000 years. The Romans ground their corn with watermills 2,100 years ago, but these were not adopted widely until 500 years later in medieval England. Finally, in the 19th century, Britain began to develop dams more than 15 metres in height to supply water to its new industrial cities. Dams of this size are now defined as 'large dams' (World Commission on Dams, 2000). In 1832, Benoit Fourneyron invented a water turbine to capture the energy of falling water, and advance on the ancient flow-dependent waterwheels. Eventually, turbines were connected to generators and the first hydroelectric plant began producing electricity in Wisconsin in 1882. Hydropower is a combination of four complex technologies, i.e. dams, turbines, generators, and electricity transmission. At last, energy from water in one location could reach another location for flexible use in multiple productive and comforting tasks (Smith, 1971).

Dams and power stations quickly grew from 30 metre heads (in 1900) to 200 metre heads (1930s) and spread rapidly in Europe and North America. In 1902, the British built the Low Aswan Dam to regulate the Nile and irrigate cotton fields, but the uptake of large dam technology remained limited in the developing world for another 50 years. After World War II, big dams began to spread to the developing world, and both India and China started to invest heavily in them. From 1950 to 1980, China built around 600 such dams per year, but quality was poor. Many dams burst, some catastrophically. For example, it has been reported that 250,000 people were killed in Henan in 1975 when 62 dams burst after an extraordinary rainfall (McCully, 2001). Dam failure rates in China appear to have been higher than elsewhere during this period.

The World Bank, other development banks, the Food and Agriculture Organization (FAO) and the UN Development Programme (UNDP) played an important role in promoting large dams and irrigation schemes in developing countries after 1970. The US Agency for International Development (USAID) and the British Overseas Development 
Administration (ODA) also helped to plan and fund dams. Such aidsupported construction companies based themselves in rich countries once the work at home had declined. The most definitive statistics on the global situation are those given by the World Commission on Dams (2000). It reported that around $\$ 20$ billion is spent every year on large dams and 100-200 are commissioned. Over the last 100 years, two trillion US dollars has been invested in 45,000 large dams worldwide. Unfortunately, few have been evaluated economically, environmentally or socially; even fewer have been systematically studied for health effects.

\section{Health and Social Effects of Dams}

Dams are built to enable socio-economic development and thus by definition, they should not make people worse off, or produce disease. However, disease caused by dams has been well documented, especially infections. Although published information on the impacts of large dams comes mostly from studies conducted in Africa and the Caribbean, there are parallel problems with dams in Asia (Hunter et al., 1993; Jobin, 1999; World Health Organization, 1999).

Many disease problems are an indirect result of the adverse social impact of large dams, especially the decapitalisation that results from the loss of land, home and livelihood. Previous capital invested is lost and for many years before the dam is built, new investment is withheld. These socioeconomic effects have been studied more extensively than health effects (Morse and Cernea, 1988, 1999; Berger, 1992; Scudder, 1997; Cernea and McDowell, 2000). However, the economic drivers needed to reconstruct shattered lives have been relatively neglected due to the short-term followup of most assessments. Dams are an important component of the ongoing global problem of human displacement, with dams accounting for millions of people affected every year. Michael Cernea, the World Bank sociologist who has done much to sensitise that institution to this problem, estimates that development programs over the last 20 years forced 200 million people

from homes and livelihoods. This exceeds the number of refugees displaced 
by conflict over the same period (Cernea, 2000). A large part of the development and displacement problem arises from large dams and the World Commission on Dams (2000) recently released informative estimates. In China alone, the official figure for the period 1950-1990 is 10.2 million, but unofficial estimates point to this number just for the Yangtze basin. In India, the number of dam-displaced persons for that same period is estimated at 16 to 38 million, and the global figure is 40 to 80 million. For World Bank development projects, large dams account for $63 \%$ of all resulting human displacement. The numbers displaced by ancillary works are not included in estimates, nor are hundreds of millions whose livelihoods were displaced by downstream effects of altered flows and other ecological changes.

Overall, dam-related vector-borne diseases have been reported frequently, especially epidemics erupting around large or small reservoirs and the associated irrigation works. These problems arise after reservoirs form and river basins change their character, creating conditions that are suitable for certain infections. The most notorious dam-associated infection and one quintessentially linked to agriculture and irrigation is schistosomiasis. This disease is variously known as bilharzia in Africa, snail fever in Asia or water belly in South America. Schistosomiasis is caused by blood flukes (schistosomes) residing in pairs inside the venous system surrounding the gastrointestinal or urinary tracts. The female constantly lays eggs that digest their way through the tissues to the faecal or urinary stream, reach fresh water and hatch into "miracidia" that infect snails present in the water bodies. They multiply inside the snails and emerge as numerous free swimming larvae ("cercariae") that infect human hosts by passing through the skin of people who enter the water. Several species of schistosome infect humans, including S. japonicum, which is endemic to a large part of central and Southern China where it also infects many domestic mammals. Schistosomiasis is present in 73 countries including much of Africa, parts of the Middle East, some Caribbean islands, several South American countries including Brazil and in China, Laos, Cambodia, the Philippines and Indonesia. There are many reports of entire communities becoming infected due to large dams and associated irrigation projects. Heavily infected people become debilitated, with weakness and loss of energy, and are eventually unable to work at all. Production falls and lifespans are shortened. Attempts to prevent snail 
breeding in reservoirs and canals by engineering modifications or chemicals have met with limited success (Jobin, 1999). In fact, infestation of tropical irrigation systems in endemic zones is so common that it is more noteworthy if problems do not arise (Hunter et al., 1993; Jobin, 2000).

Another important dam-induced infection is malaria, a disease spread even more widely than schistosomiasis. Other mosquito-borne infections associated with dams include the nematode worms that cause elephantiasis and several serious viral diseases, including Rift Valley fever, Japanese encephalitis, and dengue. In some areas of Africa and Latin America, black fly populations can breed on dam spillways and transmit the worm that causes river blindness.

Less acknowledged, but probably of greater importance, are diseases caused by poverty and poor sanitation, because they are all made worse by inadequate resettlement of people displaced and pauperised by dams. The potential list is long and includes maternal anaemia and mortality, malnutrition, and infections causing diarrhoea, pneumonia and tuberculosis. These diseases are usually present before a dam is built, often more so due to the poverty induced by the blight on private and public investment that descends on river valleys once a dam is considered, usually decades before it is built. Common diseases already present in affected populations are not usually attributed to large dams, even when they become worse after the dam is built (Sleigh and Jackson, 1998, 2001).

In addition to the infections above, the influx of construction workers and other migrants, such as fishermen or boatmen attracted by the reservoir, brings other microbial risks. Incoming migrants can introduce malaria or schistosome infection, if the vector mosquitoes or host snails are present. They also bring sexually transmitted infections, including syphilis and HIV. The influx of money and the large number of unpartnered males brings prostitution, making infection risks even higher. For a large project, the workforce may grow by 20,000 and the problems expand accordingly.

There are many other adverse health effects of large dams, but these will only be mentioned briefly as they do not involve infections. When harmless inorganic mercury in the soil of the reservoir bed is processed by bacteria feeding on decomposing vegetation, toxic methyl mercury may form; consequently, large fish at the top of the reservoir food chain accumulate dangerous levels of this neurotoxic chemical. Heavy metals and organic 
solvents may enter the water via run off from flooded factories. Algal blooms or cyanobacteria appear in eutrophic waters of tropical reservoirs soon after they fill, if flooded basins are not cleared of vegetation. Injury, often fatal, is a constant threat to construction workers. Drowning is also a risk after the reservoir forms, especially in tropical areas with no safety measures, and alcohol makes this risk higher. Less understood are the psychological problems induced by loss of land, home and work. Indigenous people are so deeply affected that they may not survive the displacement. Depression and suicide would be expected but are little studied. Violence and conflict have been reported among those adversely affected (World Commission of Dams, 2000; McCully, 2001). The conflict is thought to be a consequence of stress, poverty, communalism, and competition for resources, but is poorly documented because it is hard to trace those displaced, unless there are funds and the political will to do so.

There is also a possibility of catastrophic failure for all large dams. Reservoir-induced landslides are common and so is the seismic activity induced by the weight of the impounded water. Dam walls can collapse or be overtopped by floods or waves. One famous instance is the 1963 landslide into the reservoir behind Vaiont Dam in the Italian Alps north of Venice. A wave formed above the lake, ran rapidly in both directions, overtopped the dam, and killed 2,600 people located in several villages downstream (McCully, 2001).

\section{Water and Development}

Today, the world population is extracting 3,800 cubic kilometres $(3,800$ gigalitres) of fresh water every year from lakes, rivers and aquifers (World Commission on Dams, 2000). This accounts for over half the water available in rivers, and is six times the volume extracted 100 years ago, growing twice as fast as the population (UNDP, 2000). With world population set to increase another $50 \%$ over the next 50 years, bringing with it increased economic activity and wealth, we can expect the volume of extracted fresh water to increase much more. This means that more stress will be on hydrological resources and more people marginalised inside what UNDP calls "our fraying web of life". 
Despite the large annual withdrawal of fresh water, nearly a quarter of the world population uses less than 50 litres per person per day, approximately the minimum amount needed to prevent infection. UNDP (2000) notes that irrigation uses $70 \%$ of water withdrawn from freshwater systems for human use. Today, $17 \%$ of agroecosystems depend on irrigation, with the irrigated area up by $72 \%$ from 1966 to 1996 . Competition with other kinds of water use, especially for drinking water and industrial use, will be most intense in developing countries with fast growing populations and industries. Many of these countries are in Asia. Within Asia, several countries are already classified as water-stressed, withdrawing over $25 \%$ of annual water resources; water-stressed regions are also expanding rapidly within China and India. China, India, Pakistan and the USA account for $>50 \%$ of the world's total irrigated area. It is obvious that both agricultural water use and hydrological water stress will continue to grow within Asia, and we can expect that China and India will continue to build large dams to capture and manipulate water.

\section{Dams and Politics}

With 45,000 large dams already built, India and China continue to be the main players as they have been for decades. China reports that it is currently building 280 large dams, and India is estimated to be building somewhere between 695 and 960 (World Commission on Dams, 2000). Over the last 10 years, the most vigorous anti-dam protests have been directed at the Narmada river dams in India and the Three Gorges Dam in China. Both schemes continue to be built despite the massive negative publicity about their social and environmental impacts and considerable doubt about their economic utility (Morse and Berger, 1992; Pearce, 1992; Fearnside, 1994; Jackson and Sleigh, 2000, 2001; McCully, 2001). Over the last 20 years, the 'people affected by dams' (Declaration of Curitiba, 1997) and various environmental groups have joined together to fight many large dams. This battle is best described in McCully's comprehensive account. The World Bank withdrew from or avoided involvement in several major projects in the 1990s, including the Sardar Sarovar Dam in India and the Three Gorges Dam in China. The dam industry and governments feared the World Bank 
was withdrawing from large dams as a major development tool and this fear helped to bring the conflicting groups together for intensive dialogue and a search for evidence bearing on the debate.

In 1997, the World Conservation Union and the World Bank coconvened a productive meeting of industry and environmentalists in Switzerland (Dorcey et al., 1997; Goodland, 1997) and this led on to an independent two-year World Commission on Dams that reported back in 2000. The report produced was excellent and constituted the greatest single advance of our knowledge base of the effects and performance of large dams, but it was not well accepted by the most active dam-building governments and the World Bank was accordingly cautious as well. The report confirmed that large dams vary widely in their benefits, and they usually have substantial cost overruns and construction delays, often failing to meet economic targets, especially in relation to irrigation. They also have more negative than positive environmental impacts, and have systematically failed to mitigate the many serious and inequitable adverse social effects. To help move dialogue on, the United Nations Environment Programme is convening a series of inclusive 'Dams and Development Forums', seeking consensus about instituting the 'rights, risks and negotiated outcomes' approach advocated by the Commission. This approach recognises that reconciling competing needs and entitlements is the single most important factor in understanding dam-related conflicts. There is a fundamental need to recognise rights and assess risks (especially rights at risk), and negotiate outcomes openly rather than impose decisions on legitimate stakeholders. Unfortunately, health effects did not feature prominently in the Commission's report but WHO did make a useful submission advocating Health Impact Assessment integrated into the design and construction of all large dams (World Health Organization, 1999).

\section{Getting a Voice for the Health Sector}

In the past, most large dams had no health appraisal in the design stage unless a well known risk was apparent. Thus, if schistosomiasis or malaria were present in the area, the dam builders were cautious, aware that these two diseases could severely embarrass them if they ignored the risk and 
epidemic infection broke out after the dam was built. For the Three Gorges Dam, the risks were assessed in a general sense by using a team of medical geographers who mapped rainfall and temperature, collected scanty information on infection in the reservoir area and made a crude evaluation of potential risks (Chen et al., 1990). There was no direct study of the various affected populations and no involvement of the broader health sector already serving those populations. Central government and provincial health inputs were restricted to doing snail surveys in the area of the future reservoir to establish that the snail host was not present (Sleigh and Jackson, 1998). Thus, the 'health opportunity' approach advocated by Jobin (1999) and many others was missed, as usual. The same happened for Ertan Dam, upstream of Three Gorges, which was built near to an area previously endemic for schistosomiasis. Health assessment was restricted to managing the schistosomiasis risk (Gu et al., 2001). The other health risks, including those arising from poverty induced or worsened by the planning blight, were not addressed. For both of these large dams, a narrow curative health service was developed during the construction phase, focused on incoming workers, not integrated with local health services, and not oriented to prevention or surveillance. Such health services are typical of those provided when building large dams.

Jobin points out that knowledge about dams and disease is fragmentary and often not available to the dam builders inside their organisation. Even outside the organisation, the (few) available experts often have a rather narrow field of view. Thus, entomologists will be aware of the infections related to their discipline (such as malaria) and malacologists will have a 'snail-view' of schistosomiasis or related parasites. Neither would know much about other infections such as diarrhoea, tuberculosis, syphilis and HIV, or other health problems unrelated to infection such as depression, suicide, violence, stress and injury.

As with the recommendations emerging from the World Commission on Dams (2000) on mitigating social impacts, integrated attention to health impacts will certainly require additional investment and make dams more expensive to design and construct. At present, it is not happening due to the unwillingness to invest such funds in advance as well as the lack of familiarity of dam managers, engineers and economists with the breadth of the health risks. Narrow single discipline (i.e. one expert) assessments will rarely be 
sufficient. Multidisciplinary health teams conducting comprehensive dam health impact and opportunity assessments are needed. In the near future, the emerging health impact assessment skill being developed by many national health departments may help create both the capacity and the will to make integrated assessments of health risks of large dams. It is sorely needed in Asia, especially given the population and hydrological dynamics and the certainty of many more large dams affecting millions of people.

\section{References}

Alvares C, Billorey R. (1988) Damming the Narmada. Third World Network/Appen: Penang, Malaysia.

Barber M, Ryder G (eds.). (1993) Damming the Three Gorges. What Dam Builders Don't Want You to Know. Earthscan, London.

Brody H. (2000) Social Impacts of Large Dams Equity and Distributional Issues. (Thematic Review, World Commission on Dams). Available at http://www.dams.org/docs/kbase/contrib/soc192.pdf, Accessed 24 September 2003.

Cernea MM. (1988) Involuntary Resettlement in Development Projects: Policy Guidelines in World Bank-financed Projects. World Bank Technical Paper: 80. World Bank, Washington, DC.

Cernea MM. (1999) The Economics of Involuntary Resettlement: Questions and Challenges. World Bank, Washington, DC.

Cernea MM, McDowell C (eds.). (2000) Risks and Reconstruction: Experiences of Resettlers and Refugees. World Bank, Washington, DC.

Chen Y, Shi M, Zhao M, Chen M, Huang X, Luo X, Lie B, Wu Y, Yang L, Yan J, Wang J, Zhong D, Yao S, Fan F, Wang D, Han A (eds.). (1990) Atlas of the Ecology and Environment in the Three Gorges Area of the Changjiang River. Science Press, Beijing.

Declaration of Curitiba. (1997) Affirming the Right to Life and Livelihood of People Affected by Dams. Approved at the First International Meeting of People Affected by Dams. Curitiba, Brazil, 14 March 1997. Available at http://www.irn.org/programs/curitiba.html, Accessed 24 September 2003.

Dorcey T, Steiner A, Acreman M, Orlando B (eds.). (1997) Large Dams. Learning from the Past, Looking at the Future. World Conservation Union (IUCN) and World Bank Workshop Proceedings, April 11,12, Gland, Switzerland.

Fearnside PM. (1994) The Canadian feasibility study of the three Gorges Dam proposed for China's Yangtze river: A grave embarrassment to the impact assessment profession. Impact Assessment 12: 21-53. 
Goodland R. (1997) Environmental sustainability in the hydro industry, in T Dorcey, A Steiner, M Acreman \& B Orlando (eds.), Large Dams. Learning from the Past, Looking at the Future, pp. 69-102, World Conservation Union (IUCN) and World Bank Workshop Proceedings, April 11, 12, Gland, Switzerland.

Gu YG, Xia LF, Li ZW, Zhao MF, Yang HY, Luo QY, Xia WH, Feng QY. (2001) Study on schistosomiasis control strategy in Ertan reservoir. Chinese Fournal of Parasitology and Parasitic Diseases. [Zhongguo Fi Sheng Chong Xue Yu Fi Sheng Chong Bing Za Zhi].(In Chinese, English Abstract) 19: 225-228. (In Chinese, English Abstract).

Hunter JM, Rey L, Chu KY, Adekolu-John EO, Mott KE. (1993) Parasitic Diseases and Water Resource Development. WHO, Geneva.

Jackson S, Sleigh A. (2000) Resettlement for China's three Gorges Dam: Socioeconomic impact and institutional tensions. Commun Post-Commun Studies 33: 223-241.

Jackson S, Sleigh AC. (2001) Political economy and socio-economic impact of China's three Gorges Dam. Asian Studies Rev 25: 57-72.

Jobin W. (1999) Dams and disease. Ecological Design and Health Impacts of Large Dams, Canals and Irrigation Systems. E \& FN Spoon, New York.

Landes D. (1998) The Wealth and Poverty of Nations. Little, Brown and Company, London.

Morse B, Berger T. (1992) Sardar Sarovar. Report of the Independent Review. Resource Futures International, Ottawa.

McCully P. (2001) Silenced Rivers. The Ecology and Politics of Large Dams. Zed Books, London (enlarged and updated edition).

Pearce F. (1992) The Dammed. Rivers, Dams and the Coming World Water Crisis. The Bodley Head, London.

Scudder T. (1997) Social impacts of large Dam projects, in T Dorcey, A Steiner, M Acreman \& B Orlando (eds.), Large Dams. Learning from the Past, Looking at the Future, pp. 41-68, World Conservation Union (IUCN) and World Bank Workshop Proceedings, April 11, 12, Gland, Switzerland.

Sleigh AC, Jackson S. (2001) Dams, development and health: A missed opportunity. Lancet 357: 570-571.

Sleigh A, Jackson S. (1998) Public health and public choice: Dammed off at China's three gorges? The Lancet 351: 1449-1450.

Smith NAF. (1971) A History of Dams. Peter Davis, London.

UNDP. (2000) A Guide to World Resources 2000-2001. United Nations Development Program, World Bank, World Resources Institute, Washington, DC. Available at http://www.undp.org/dpa/publications/ExecSumWeb.pdf, Accessed 20 October 2004.

Wittfogel KA. (1957) Oriental Despotism: A Comparative Study of Total Power. Yale University Press, New Haven. 
World Commission on Dams. (2000) Dams and Development. A New Framework for Decision Making. Earthscan Publication, London. Available at http://www.dams.org/, Accessed 3 May 2005.

World Health Organization. (1999) Human Health and Dams. WHO: Geneva (submission to the World Commission on Dams). Available at http://www.dams.org/docs/kbase/working/health.pdf, Accessed 3 May 2005. 